\title{
Left Button Picture, Right Button Bomb: Nature, Warfare and Technology in a Southern African Border Region
}

\author{
JAMES MERRON \\ UNIVERSITY OF BASEL \\ SWITZERLAND
}

\author{
LUREGN LENGGENHAGER \\ UNIVERSITY OF BASEL \\ SWITZERLAND
}

\begin{abstract}
In this paper, we argue that the relationship between nature conservation and warfare was and continues to be actualized through socio-technical relationships and shared infrastructures. We historicize "green militarization" - defined as the use of military techniques, technologies and partnerships in the pursuit of conservation (Lunstrum 2014) - showing that the partnership between military and nature conservation in Southern Africa has a long and violent history. Our paper accounts for the entanglements of war and nature through a shared technological infrastructure used in north-eastern Namibia during the Namibian War of Liberation (1966-1989). In particular, we focus on the Mirage IIIR2Z, an aerial reconnaissance and groundattack supersonic jet which provided both the South African Defence Force and the civil administration's nature conservationists with aerial photography and remote sensing data. The spatial information produced jointly by the military and the civil nature conservation department was used to produce strategic maps, but also to fight invasive plants and protect wildlife. Our reading of green militarization against this background sheds light on the long-lasting connections between warfare, conservation and ecology along Southern African border regions and contributes to a novel understanding of the contemporary "war on poachers" through a study of the techno-scientific networks that made it possible. Since there is nothing inevitable about the way technologies emerge or change over time (Bijker and Law 1992), this paper develops an empirically grounded and sustained analysis of technological change in the domain of green militarization through three interlinked concepts: "multiple" (Law 2002), "shifting down" (Latour 1994; 1999), and "firming up" (Bijker and Law 1992).
\end{abstract}

\section{Keywords}

nature conservation; Namibian War of Liberation; Southern Africa; aerial photograph; green militarization

\section{Introduction: Green Militarization}

Late at night on July 27, 2012, the Botswana Defence Force (BDF) shot two Namibian fishermen dead in their canoe as they were making their way from one side of the Chobe River to the other. According to a spokesperson of the BDF, the two men were hunting an elephant in Botswana's Chobe National Park and 
were trying to bring back the tusks into Namibia. Later, an investigation led by an international team of journalists could not find any evidence of fresh ivory in the canoe. What they were able to uncover, though, were the forensic details of the shooting. The fishermen were shot from behind, and the weapons they were carrying-a 22-caliber rifle and a 12-gauge shot shotgun-would not have been big or accurate enough to shoot down an adult elephant (Ntibinyane et al. 2016).

Over the last twenty years the BDF has killed more than 50 people from Namibia and Zimbabwe because they were suspected of crimes against wildlife and hunting regulations, although human rights groups estimate the figure to be much higher (Global Witness 2021). The last incident, so far, happened in November 2020 when the BDF fatally shot a family of four in a canoe at the Namibian border, escalating tensions between the two countries (The Namibian 2020a). The situation was a result of Botswana's "shoot to kill" policy. Map Ives, who was in charge of Botswana's fight against rhino poaching, explained by interview to us in 2015, "Botswana's president as a trained soldier has a no-bullshit tactic. We have laws and we enforce those laws. If you don't obey the law, you can die. If you go to a national park with a gun you commit a violent crime, and the president as a soldier he will use violence against you."

Near the site of the 2012 killings, but about thirty years earlier, a pilot of the South African Airforce (SAAF) flew a Mirage IIIR2Z fighter-reconnaissance jet over the bushland along the border region of northeastern Namibia. His mission on this occasion was exceptional in that the pilot was not using the jet (called Vlamgat ${ }^{1}$ ) to bomb the camps of Namibian refugees living in Southern Angola, nor was he targeting hideouts used by the People's Liberation Army ${ }^{2}$ or Angolan MiG's. ${ }^{3}$ This time, the pilot's mission was solely to take photographs for military reconnaissance and-more surprisingly-ecological surveying for South Africa's civil local administration. Unlike in many other instances, no bomb was dropped in this deployment, and no one died directly from it. The capacity of these fighter jets to drop bombs and to take pictures emerged as a topic of interest from a statement made by a retired South Africa Air Force pilot while showing us inside the cockpit of a decommissioned Mirage IIIR2Z at the South African Air Force Museum in Cape Town. During our visit to the museum he pointed to the control lever and said "left button picture, right button bomb" [Visit 28.03.2014]. Both the killing of the fishermen at the border and the use of the Mirage for nature conservation were instances of green militarization, and the pilot's statement epitomizes the relation between nature conservation and militarization.

Green militarization is defined as the use of military techniques, technologies and partnerships in the pursuit of conservation (Lunstrum 2014, 817). This concept has been influential in political ecology and in recent analyses of neoliberal conservation approaches (Ybarra 2012; Büscher 2016; Büscher et al. 2015; Dunlap et al. 2014; Lunstrum 2015; Massé et al. 2016).4Today, nature conservation policies in Southern Africa

\footnotetext{
${ }^{1}$ The "Vlamgat" of the South African Airforce refers to the jet-pipes of the fighter aircraft (Hayes 2001).

2 PLAN (The People's Liberation Army) was SWAPO's military wing that fought the war in northern Namibia and southern Angola.

3 The Russian Aircraft Corporation is commonly known as Mikoyan or MiG.

4 The context of north-eastern Namibia shows, both historically and more recently, that there have been diverse forms of a military-conservation nexus. The diversity of relations between nature conservation and war has also
} 
are often criticized for remaining deeply rooted in a colonial and apartheid past, despite - or even because of-the rhetoric of community-based and bottom-up development (Singh and Van Houtum 2002; Garland 2008; Mavhunga 2014). These continuities are more than just discursive and can be seen in diverse forms; amongst them the upholding of colonial and apartheid spatial configurations and land ownership regimes (Ramutsindela and Sinthumule 2017), the (re-)conceptualization of local people as part of a pristine nature, or the strong investment of apartheid financial capital in conservation NGOs (Spierenburg and Wels 2010). Other continuities include the important role that former military personnel still play in educating antipoaching units, the promise of economic benefits for "local communities" to ensure they remain loyal, or the role of national and international donors and (weapon) companies in supplying and financing "wars" against alleged poachers (Lunstrum 2015; Spierenburg and Wels 2010; Marijnen 2017).

Against this background, we argue that the relationship between nature conservation and warfare was and continues to be actualized through socio-technical relationships and shared infrastructures. Our analysis is set geographically at the border region, between Namibia, Angola, Zambia and Botswana and historically in the period of the Liberation War (1966-1989). Using this case study, we add a historical layer to understanding the formations and linkages between the South African Defence Force and conservationists that are currently evident along Southern African border regions. To unpack our study, we discuss the entanglement of warfare with nature, as well as with the civil and military efforts to control nature using technologies that mediate spatial knowledge. The exact knowledge of the region's nature was a crucial asset for all involved parties (Russell et al. 2004) and the important role nature played in the Namibian War of Liberation is even reflected in its common name, the "Bush War" (Hayes 2001; Dale 2014). The trope of fighting not only against a human animal but against a hostile and brutal environment is common in soldiers' memories of war-in northern Namibia and beyond (Breytenbach 1997), notably during the Vietnam War (Marlantes 2009). In addition, there is also an entanglement between war and the effort to control nature, as our example of the fight against an invasive plant, Salvinia molesta, will show.

As the intersections between conservation and security expand, it is apparent that we need additional tools to comprehend how they come together and what their impact is (Lunstrum 2018, 1026). The social history of science and technology offers a means through which to contribute to the scholarship on the political economy of partnerships between conservation and military. In this article, we attend to the socio-technical relationships that shape and are shaped by heterogeneous groups and interests, as well as forms of evidence about this heterogeneity. In our case these are infrastructures that the South African

been reflected in scholarly literature. There has been ongoing research on the impact of warfare on the environment-or war in nature, often referring to Arthur Westing's seminal work on warfare in South East Asia (Westing 1976; Tucker et al. 2004; Certini et al. 2013; Lawrence et al. 2015; Massé et al. 2018). Furthermore, there has been a thorough engagement with military involvement in conservation during conflicts (Ellis 1994; Verweijen et al. 2018; Lenggenhager 2018), the role of the military in securing conservation areas and goals (Wels 2015; Barbora 2017), the military's role in conservation as a specific part of how politics and state power shape relations between society and nature and vice versa (Neumann 2005; Robbins 2012), and the closeness of military conservation and anti-terror measurements (Duffy 2016). 
Defence Force shared with civil administration, particularly for its nature conservation division. Such an interplay of military technology and civil administration-or more broadly technology and societytherefore provides a framework for understanding how sets of technological arrangements, such as fighter jets that produce aerial photography, are established and maintained (ibid., 8).

The integration of Science and Technology Studies (STS) and green militarization enriches both bodies of literature. While STS puts attention on the social construction of technologies and technological systems (ibid.), green militarization lends itself an analysis of the intersection of military technologies and techniques in the domain of the environment (Lunstrum 2014) which is part of a broader literature on the confluence of military interests and research technologies (Shinn \& Bernward 2002), datafication (Edwards 1997), remote sensing (Bousquet 2018), and the production of spatial knowledge about the environment (Mack 1990). We employ this framework to account for a common infrastructure used by nature conservationists and military personnel on Namibia's northern border between the 1960s and 1980s, an intimate constellation of heterogenous actors and artefacts that has continued to interact up until the postcolonial present. Whether fighter jets or drones, STS concepts help us unpack the processes in which artefacts and their inscriptions shape and are shaped by the interaction of society and technology shedding light on recent political debates about the use of military tactics, technologies and violence in wildlife conservation in Southern Africa.

In what follows, we first outline the historical context and explain the ecological issues that triggered a shared infrastructure. This state of affairs adds to an existing body of work in Science and Technology Studies (STS) that accounts for particular technologies and technological systems and how they move from the domain of military to public use (ibid.; Edwards 1997; Shinn \& Bernward 2002; Bousquet 2018). The second part of the paper takes up concepts and terminologies from STS - such as "multiple" (Law 2002), "shifting down" (Latour 1994; 1999) and "firming up" (Bijker and Law 1992) - and applies them to the analysis of archival sources from the South African Air Force Museum in Cape Town. Our conclusion highlights the heterogeneous factors that gave rise to an infrastructure that was shared by nature conservationists and military personnel during the Namibian War of Liberation, offering both a unique approach to green militarization as well as to the social life of particular technologies and technological relations (ibid.). These histories, archival sources and theoretical approaches elaborate on green militarization as an alignment and convergence at the confluence of conservation, militarization, the state, and the economy (Massé et al. 2016,123) that are mediated by technologies with multiple purposes (Law 2002) and networks of distributed action (Latour 1994).

In order to elaborate on the shared infrastructure between the military and nature conservation we develop a Latourian analysis of the dual use function of the Mirage IIIR2Z military reconnaissance jet through which to attend to the social and technical delegates that actualize its capacities to drop bombs or take pictures. Based on this account, mediated action is not the property of an individual person but of an association of entities which change each other offering new possibilities, goals and functions (Latour 1999, 188). However, while Latourian analysis makes visible the many delegates that stabilize a network across time and space, it lacks an adequate framework to account for the conditions within which technologies and technological arrangements emerge. Bijker and Law (1992) help widen the scope of analysis by arguing that technology-or technological arrangements - emerge from a set of relations. These relations be they social, scientific, economic, or organizational are (like technology) heterogeneous, emergent and contingent (ibid., 
8). The notion of "firming up" therefore accounts for how technologies are stabilized within a network of relations and strategies which, when meshed together, form emergent phenomenon and objects of investigation-like for instance the Mirage. This framework leads us into larger discussions about the politics of nature conservation and the social relevance of technological change in the context of green militarization.

\section{Nature and Militarization: South Africa's Caprivi Strip}

The geographical focus of this paper lies on the extreme north-eastern part of Namibia, the so-called "Caprivi Strip," consisting today of the Zambezi Region and parts of the Kavango East Region. ${ }^{5}$ The area was allocated to Germany in a contract with Britain in 1890, but the first permanent German colonial official was stationed there only in 1909. Six years later, German colonial authority was replaced by South African rule over Namibia and the declaration of martial law in July 1915. In 1920, the League of Nations accorded South Africa the mandate over what is today the territory of Namibia, including the Caprivi Strip. But implementing control over these areas in the extreme north-east proved difficult. High administrative costs and the prospects of meagre profit led to skepticism about the (economic) worth and viability of occupying the area. However, the parameters shifted in the late 1950s, once independence from British colonial rule gained significant ground across the Southern African region. Several factors contributed to turning the Caprivi Strip into a region of critical strategic importance to the South African regime and later into a battle zone against its liberated neighbors: Zambia's independence in 1964, the beginning of armed resistance by the South West African People's Organization (SWAPO) in northern Namibia and by the Caprivi African National Union (CANU) in north-eastern Namibia in 1966, the Angolan independence in 1976, and the instalment of Namibian resistance and refugee camps in Southern Angola (Lenggenhager 2018).

During the 1960s-80s, the Caprivi was a military frontier for both SWAPO's armed wing-the People's Liberation Army of Namibia (PLAN) - and the South African Defence Force (SADF), making the small corridor one of the most heavily militarized areas in Southern Africa (Kangumu 2011). At the same time the Caprivi Strip became a symbolic trench for South Africa's apartheid regime, which turned the region into a first line of defense, a training base for their armed forces (especially their special units), and a springboard for attacks on and the destabilization of countries adjacent to the frontier (ibid.).

From the late 1960s, the SADF built up at least seven large camps and two major airports in the region (including Mpacha airbase in Katima Mulilo). It was also in the Caprivi Strip where the South African

5 The Caprivi is still a widely used term referring to the entire geographical region of the Caprivi Strip, consisting of the present-day Namibian Zambezi Region (formerly the Caprivi Region, under South African rule known as the Eastern Caprivi or East Caprivi) and the area that is commonly known as West Caprivi, today split between the two Namibian regions of Zambezi and Kavango East. As it is often the case with changes of colonial names there is an intense and highly politicized debate behind the naming of the area that is beyond the scope of this paper. To keep things simple, we refer to the area as Caprivi for the time of South African occupation and refer to it as Zambezi Region for more recent times. We also use north-eastern Namibia and Caprivi Strip to refer to a less strictly defined larger geographical region. 
forces trained some of their infamous special units, such as the Reconnaissance Commandos, the "Buffalo Battalion" or later, "Koevoet." However, the Caprivi Strip was not only a military outpost. In 1964 the Odendaal Commission proposed the establishment of homelands for Namibia, and as a consequence the Eastern Caprivi was turned into a pseudo self-governing South African "homeland" (Lenggenhager 2018). ${ }^{6}$

South Africa's understanding of its military presence in northern Namibia during the later years of apartheid was reflected in a counter-insurgency approach known as the "total strategy," which called for more than mere military occupation. It sought tighter control over all activities in the area by including "non-combatant" elements, such as political and economic measures, and increased surveillance. The SADF promoted these non-combatant aspects of its occupation as the Winning the Heart and Minds (WHAM) campaign. This was grounded in the basic doctrine of winning "the sympathy and support of the people upon whom the insurgents depend" (Eloff de Visser 2011, 86). Although the SADF had its own unit dedicated to this effort, the so-called Civic Action Programme, the civil administration had an important role to play as South African government officials or civil servants were less likely to be associated with the atrocities of the SADF. In north-eastern Namibia, it was the civil administration's efforts managing the region's nature, such as fishery and forestry, that was seen as especially helping to "win" the locals' loyalty. In the late 1970s, the administration added numerous conservation efforts to these tasks, as conservation, forestry and the fishery were expected to become profitable for the homeland once the war was won (Lenggenhager 2018).

\section{Knowing Nature to Win the War}

The war in northern Namibia required both nature conservationists and the military to acquire intimate knowledge of the region. To this end, they deployed state-of-the-art machinery and gathered geographical and ecological information from local residents. The need to know the natural environment thus became a catalyst for establishing the relationship between the military, local communities and scientists -a relationship forged in a strategically named theatre of war, i.e. in what the South African administration and armed forces called "The Bush War." A former member of the South African Air Force (SAAF) cut right to the chase of reconnaissance: "Knowing nature was and still is essential to win a war. Particularly in the Bush War, the bush was the only thing we shared with our enemies, for both of us, nature was enemy and ally." (quoted in: ibid., 148). This quote echoes Edmund Russell and Richard P. Tuckers' observation that nature "has long been an ally of peoples at war" to provide food, shelter, and raw material-while a lack of knowledge of or an enemy attack on nature always posed a "threat to armies" (Russell et al. 2004, 6).

The entrenchment of military operation, ecological research and later nature conservation included the use of shared infrastructure in the daily routines of nature conservation officers, researchers, and army and police personnel in the region's administrative center of Katima Mulilo. The town was also used as a Defence Force military base. Situated far beyond the South African heartland, it emerged as a remote

${ }^{6}$ For an overview of the concept and historiography of South African homelands, see: Ally et al. (2018) and Jensen et al. (2015). 
outpost, where a strong but isolated white community carried itself as the "anti-communist bulwark and bastion of white Western values" (Kangumu 2011, 155-156).

Even after Namibia's independence in 1990, armed skirmishes related to the civil war in Angola and a secessionist movement perpetuated heavy militarization of the Zambezi region. In spite of this, the new government and private investors began to promote tourism and conservation as pillars of regional economic development. A few years after the end of the war in Angola, and the following gradual demilitarization of the region, the Kavango-Zambezi Transfrontier Conservation Area (Kaza TFCA) was proclaimed in 2011, stretching over the borders of Namibia, Botswana, Zimbabwe, Angola and Zambia. This so called "Peace Park" is today part of a network of transfrontier conservation areas along many borders in Southern Africa, advanced by the South African Peace Park Foundation and supported by all Southern African governments.

Peace Park's approach has been criticized as neoliberal and neocolonial; a top-down scheme that failed to live up to the promise of peace, economic stability and wildlife conservation (Ramutsindela 2007; Büscher 2013). As a matter of fact, many transfrontier conservation areas became instead sites of green violence and green militarization (Lunstrum 2015; Büscher et al. 2015; Lenggenhager 2018; Witter \& Satterfield 2019), where public-private partnerships promote the development and transfer of technology to buttress a war against poaching. ${ }^{7}$ These technologies include not only guns, but also drones, sound traps and other intelligence gathering equipment, which were used to extract ecological knowledge. In other words, the shared grounds of counterinsurgency and nature conservation in northern Namibia have drawn on what we wish to call "dual use" technologies, i.e. technologies that have transitioned from one domain to the other.

In the following section, we describe one instance of the conjunction of dispersed desires for reconnaissance, namely the control of an alien plant. On that occasion, soldiers and scientists closed ranks in order to harness knowledge and infrastructure against invasive others, humans and non-humans alike.

\section{A Shared Enemy: Salvinia Molesta}

Salvinia molesta, an invasive plant in northeastern Namibia, can be used as a lens through which we can look at the idiosyncratic relationship between nature conservationists and military personnel during the Namibian War of Liberation. The need to observe and control this plant provoked the constitution of a shared infrastructure and a common knowledge base. A focus on S. molesta also helps explain the particular epistemology of space established since the mid-twentieth century that engenders conservation in the region to the present.

\footnotetext{
${ }^{7}$ Büscher and Ramutsindela define green violence as "the deployment of violent instruments and tactics towards the protection of nature and various ideas and aspirations related to nature conservation" $(\underline{2016,6)}$. Green violence was developed as a way to broaden green militarization.
} 


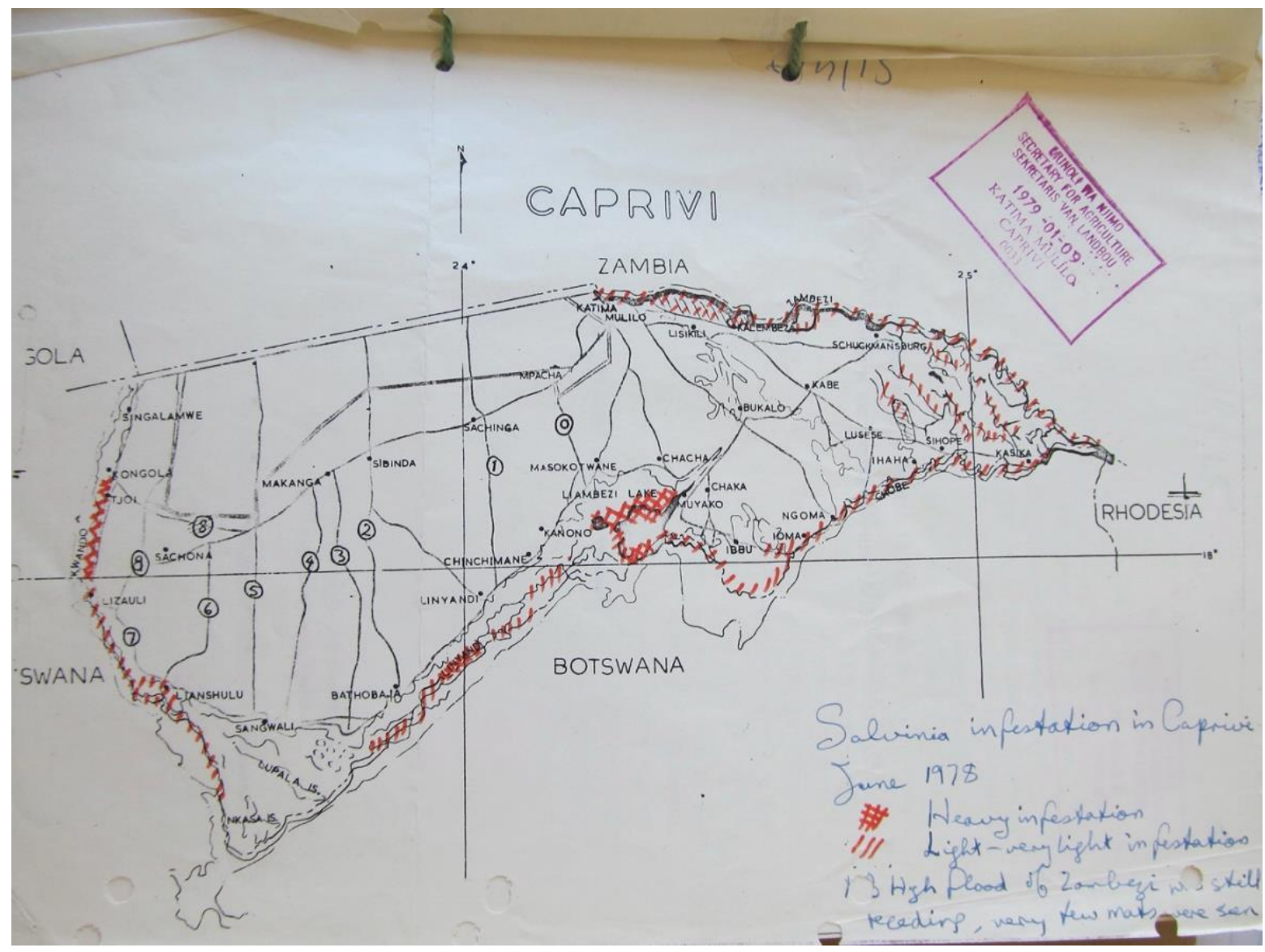

Figure 1. Map of S. molesta infestation, 1978. (National Archives of Namibia, CAF 2016).

S. molesta is an aquatic fern that has been found in the river systems of the Chobe, Liniyanti and Kwando rivers since the 1950s. The construction of the Kariba Dam in 1959 led to the spread of this species, which exploded in the Zambezi river and eventually covered large expanses of water and led to eutrophication. ${ }^{8}$ The aquatic plant grows in open water sources very quickly, making it difficult to fish and nearly impossible to control boat traffic on and across rivers. For the military, S. molesta posed a strategic disadvantage as it made the surveillance of the river more difficult and could be used as cover by enemy fighters. The civil administration was particularly concerned with the negative consequence of S. molesta on the 'development' of fisheries and later tourism, since these were seen as rare economic potentials in the newly created homeland and a critical factor in maintaining loyalty to South Africa's occupying power.

The survey and control of S. molesta, concurrently declared an invasive alien species and a threat to military operations and the profitable use of the region's natural resources, became a domain in which the

${ }^{8}$ Eutrophication happens when a body of water becomes overly enriched with minerals and nutrients which induce excessive growth of algae. This process may result in oxygen depletion of the water body. 
cooperation between military personnel and nature conservation officers materialized. In this particular task they shared the objective of keeping South Africa's Namibian territory clear of enemies, both "terrorists" and "alien species." Figure 1 shows one of several maps produced commonly by conservationists and military personnel, and it specifies the invasion of S. molesta along Caprivi's borders.

The "fight" against S. molesta was chronicled in reports produced from the late 1960s up to at least 1978 and documented in frequent aerial surveys. Regional expert networks were also established, and the South African Airforce provided planes, pilots and aerial photography, as well as interpreters, who documented and analyzed the distribution of the alien plant (Lenggenhager 2015, 475; Bollig and Vehrs 2021). The relationship between conservationists and the military intensified in this period, establishing a shared infrastructure of new knowledge, tools, weapons and technologies that could be deployed in the fight of a literal and metaphorical common enemy.

\section{Aerial Photography}

Figure 2 labelled "Ngoma Bridge" exemplifies the concomitant visual epistemology that placed ecological features and, more specifically, the spread of $S$. molesta along the river in relation to strategic infrastructure which secured South African control of the border area.

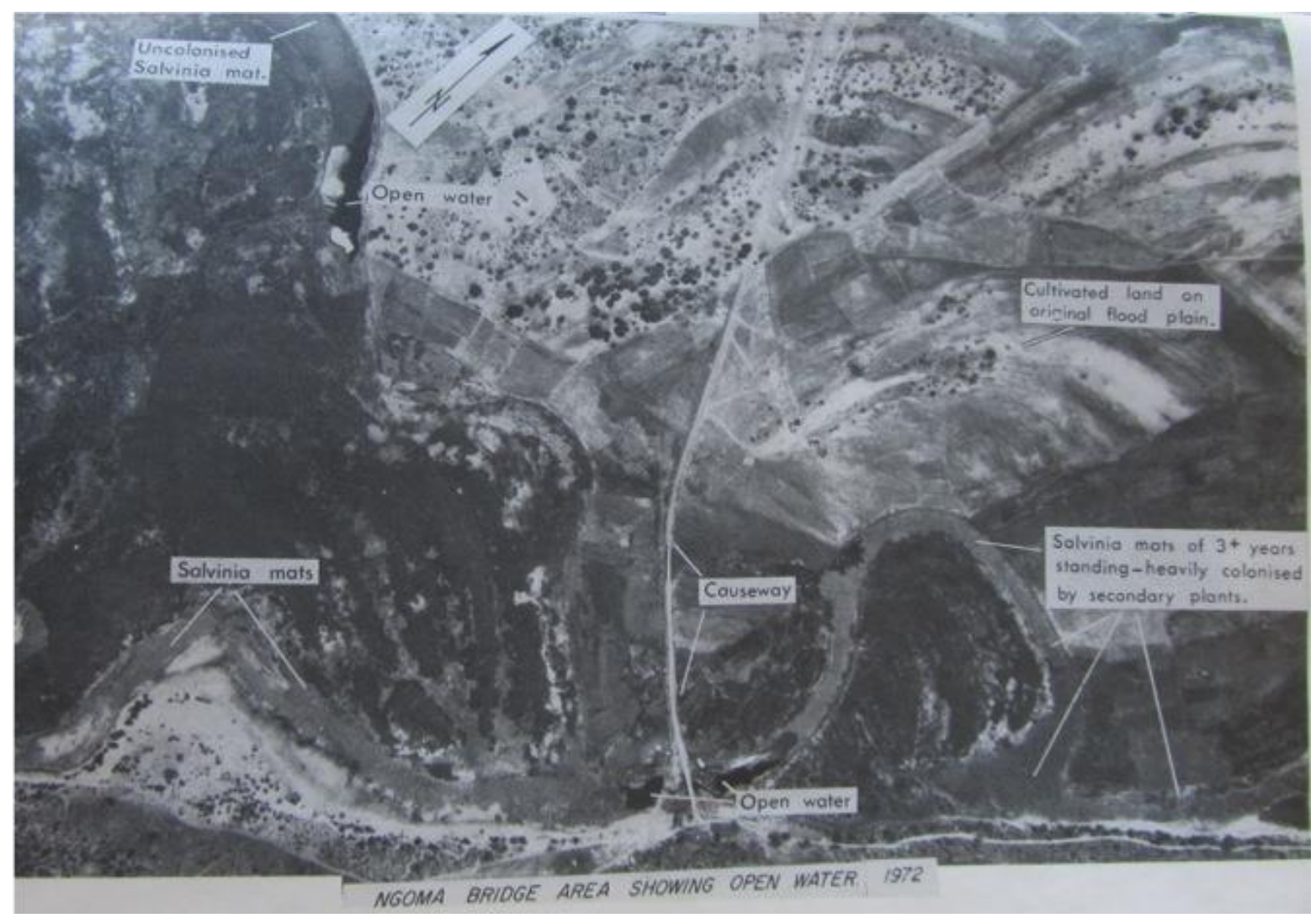

Figure 2. Ngoma Bridge. (Edwards and Thomas [1979] 2016, 20). 
The image is part of an emerging scopic regime based on aerial photography for military reconnaissance and environmental surveying and mapping in the Caprivi during the Liberation War. The medium and technology was constitutive of a perception of space which engendered the establishment of nature conservation areas at the time, and which continues today. Aerial photography also facilitated the transformation of north-eastern Namibia from a military battleground into a domain for tourism and conservation, whereby it helped conceal the transfer of a military rationality into the civil realm. As Lunstrum has rightly pointed out, "once conservation practice is militarized, it stays militarized" (Lunstrum 2014, 825). Because conservation and war were so closely linked in the Caprivi, militarization never fully ceased, and military tools, strategies and personnel maintain a critical role in shaping nature conservation. This is especially evident, we wish to argue, in the assemblage of technologies through which the surveillance of space is enacted.

Aerial photography was applied in the Namibia-Angola war zone as part of a sophisticated infrastructure built to conduct reconnaissance and attack flights into enemy territory in Angola and Zambia. As a technical and cultural by-product of warfare, it also served to produce ecological data on the region which was shared with nature conservationists. The SADF used aerial photographs to garner geographical and cartographical information to describe the distribution of material objects and natural features across the surveyed landscape, especially enemy camps. Yet the same images served nature conservationists in their endeavor to gather accurate information on wildlife, fish populations and vegetation, among them $S$. molesta, which posed a strategic threat to both the military and civil administration.

The smooth transition of aerial photographic images between military and civil domains and their legibility in both fields, was predicated on the fact that it was an element within a technological assemblage of practices, devices and institutions (Rizzo 2019). There are therefore specificities to the production of the Caprivi maps and images, that link them to a "shared infrastructure." This infrastructure shifts our attention to different social and technical agents including the South African Air Force and the Department for Native Affairs as well as the technologies used; such as planes, cameras, theodolites and stereoscopes which are all parts of the "complicated material, institutional, and technological networks within which aerial photographs were produced, circulated, and deployed" (ibid., 160). The emergence of aerial photography had two broad functions in South Africa, first, for use in soil erosion debates in the 1920s and then second, for mapping in the 1930s through which the state could engage with agricultural transformation and engage with space. Both instances carried political and ethical issues, and the dominant actors using aerial photography were within the state apparatus, namely the military. Shortly after, the ability was transferred to experts and academic institutions (ibid.).

The production of aerial photography in South Africa exposes the profound interests in space harbored by both the military and civil administration, which is the focus of the next section. We accomplish this by attending to one of the many devices that mediated aerial photography, the Mirage IIIR2Z.

\section{Technical Mediation: The Mirage IIIR2Z}

The first production standard of the Mirage III (2019) was built in 1963 by the French aviation company Dassault and was armed with an assortment of missiles (Brindley 1971, 177). Its versatile design was soon adapted to a variety of roles as a training unit (IIIDZ), bombers (IIIEZ) and ground attack version (IIICZ). In addition, a number of dedicated reconnaissance variants of the Mirage III were developed and produced 
under the general designation of Mirage IIIR. Compared to the other models, the IIIR had a nose with several glass apertures for medium format cameras, housing up to five OMERA cameras. ${ }^{9}$ Later versions of the IIIRs were fitted with British Vinten cameras and an extra panoramic camera at the most forward nose position, along with Doppler radar and other avionics including an infrared line scan or a side looking airborne radar (Jackson 1993, 132-133)..$^{10}$

Variants of the Mirage III formed the bulk of the South African Air Force's fleet. The planes were built in France and shipped to South Africa, where they were initially received by the No. 2 Squadron at Waterkloof which later relocated to Hoedspruit while the SAAF and SADF were involved in operations against neighboring southern African countries. In the early 1970s, some planes moved to the No. 3 Squadron and the No. 85 advanced flying school at Pietersburg, performing operations in Rhodesia (now Zimbabwe) and Mozambique. More extensive ground attack operations were conducted against forces in Angola during the Namibian War of Liberation and the Angolan Civil War (Jackson 1985, 59). For these purposes the Mirage fleet were typically flown from Mpacha Airbase near Katima Mulilo.

The Mirage IIIR2Z - a variant of the Mirage IIIR - was capable of producing aerial photographs and remote sensing data, and was also used for tactical strikes and reconnaissance. It had improved photo reconnaissance equipment plus a higher performance engine, the Atar $9 \mathrm{~K}-50$, manufactured with exact specifications for the South African Air Force by Dassault. The Mirage IIIR2Z is considered to have been the fastest fighter jet which the SAAF ever used (Lord 2008). In the 1970s and 1980s it was involved in reconnaissance flights over the Caprivi, Zambia and into Angola as well as in ground attacks on military and refugee camps including the brutal strike on the Cassinga refugee camp in southern Angola that killed hundreds of civilians in 1979 (Williams 2015). The dual functionality of the Mirage IIIR2Z blurs the boundary between a war machine and a scientific instrument, offering both surveillance and tactical response capabilities which were ultimately effective in defining and controlling space.

Given the variety of roles, we can look at the Mirage IIIR2Z not only as an object, but also a multiplicity - for instance in wing shape, speed, military roles, and political attributes (Law 2002, 2). The plane can therefore be considered as many and quite different things. It is not a single object but many parts of a single object (ibid., 14-15). In other words, the warplane is a whole assortment of various machines, which are orchestrated differently using different strategies and mechanisms that coordinate its disparate elements, from the mediation of violence to the leaving of cartographic traces. This multiplicity is maintained by a whole series of associations between technical and institutional "delegates" (Latour 1994; 1999): the plane, the engines, the camera, the bombs, the control lever, the pilot, the engineers, airports, bases and even centers of command in Pretoria.

${ }^{9}$ OMERA is a French company that had supplied cameras to several armies, including the United States of America and South Africa. The cameras were designed specifically for producing aerial photography.

10 This extra photographic equipment severely diminished the IIIR supersonic performance compared to the nonreconnaissance variants like the IIID2Z. Also, the mediocre performance of the fighter's Cyrano II radar effectively precluded the type from conducting night-time operations, as well as during challenging weather conditions (Lord 2008). 
In order to understand how the Mirage IIIR2Z fits within the conservation-military nexus, we need to address the whole chain of associations that are involved in order for the plane to mediate violence, aerial photographs and the collection of ecological data. Employing the terminologies of Bruno Latour's account of "technical mediation" $(1994 ; 1999)$ helps us understand the background associations that went into forming aerial photographs, which emerged out of the shared infrastructure of military and scientists. Agency is distributed within this network - which, when working in cooperation-makes possible the choice of a particular pilot to either press the left button to take a picture or the right one to drop a bomb. The crux of the matter is that when these many delegates mediate the production of an aerial photograph used by nature conservationists, they become part of the social assemblage we can identify as green militarization. The shift of perspective makes the range of technical artefacts and expertise assembled to produce aerial photographs visible for analysis.

As a product of coordinated activity between silent actors working in the background to make mediation possible, the Mirage IIIR2Z is what Bruno Latour calls an "object institution" (ibid., 189-192), which is a frame of reference that decenters the actions of any one individual, turning analytical attention to the coordinated activity of all actors in the network working together as a heterogeneous assemblage of humans and technical objects. In this frame of reference, it is not the pilot who flies the plane, takes pictures of "alien plants" or drops bombs on refugee camps but rather a whole network and infrastructure that includes planes, pilots, dark rooms, institutions, departments and even propositions. In Latour's words: "Flying is a property of the whole association of entities that includes airports and planes, launch pads and ticket counters. B-52s do not fly, the U.S. Air Force flies. Action is simply not a property of humans but of an association of actants" (ibid., 35). Similar to Latour's point about the B-52s, it is not the pilot alone taking an aerial photograph but - at the same time - a whole network of people and things that produce a particular photograph taken from the Mirage IIIR2Z.

\section{"Shifting Down"}

The ability to produce an aerial photograph was not the property of the Mirage IIIR2Z nor the pilot, but the outcome of an assortment of technologies and people (see figure 3 and figure 4). By "shifting down" through all the frames of reference that have been assembled into a single picture of the landscape, we gain insight into its production which was made possible by many silent actors and technical delegates (ibid., 188-193). In other words, many actors were indispensable when it came to putting planes in the sky so that it could either take a photo or drop a bomb. Behind the production of the aerial photograph is the act of flying, which can be shifted down to planes, engines and pilots. The planes included a whole network of engineers, air traffic controls and equipment, all acting through institutional and technical delegates whom-although distant in time and space-were constituted as an association of entities involved in accomplishing a particular inscription (the aerial photograph).

"Shifting down" means that the photograph can be linked to actions long past and long disappeared. At this stage, we no longer focus on one object-the Mirage IIIR2Z-but now see people gathered around an object, with particular associations to one another and with similar or divergent programs of action (ibid., 188-9). As a combination of absences and presences of people, shifting makes visible the skills and objects that occupy a crucial function but are invisible in the final result. In terms of our understanding of green militarization, this form of analysis gestures toward a more micro-historical 
perspective on the practices in which particular interlinkages between military and nature conservation were enacted, by whom and through what socio-technical assemblages and shared infrastructures.

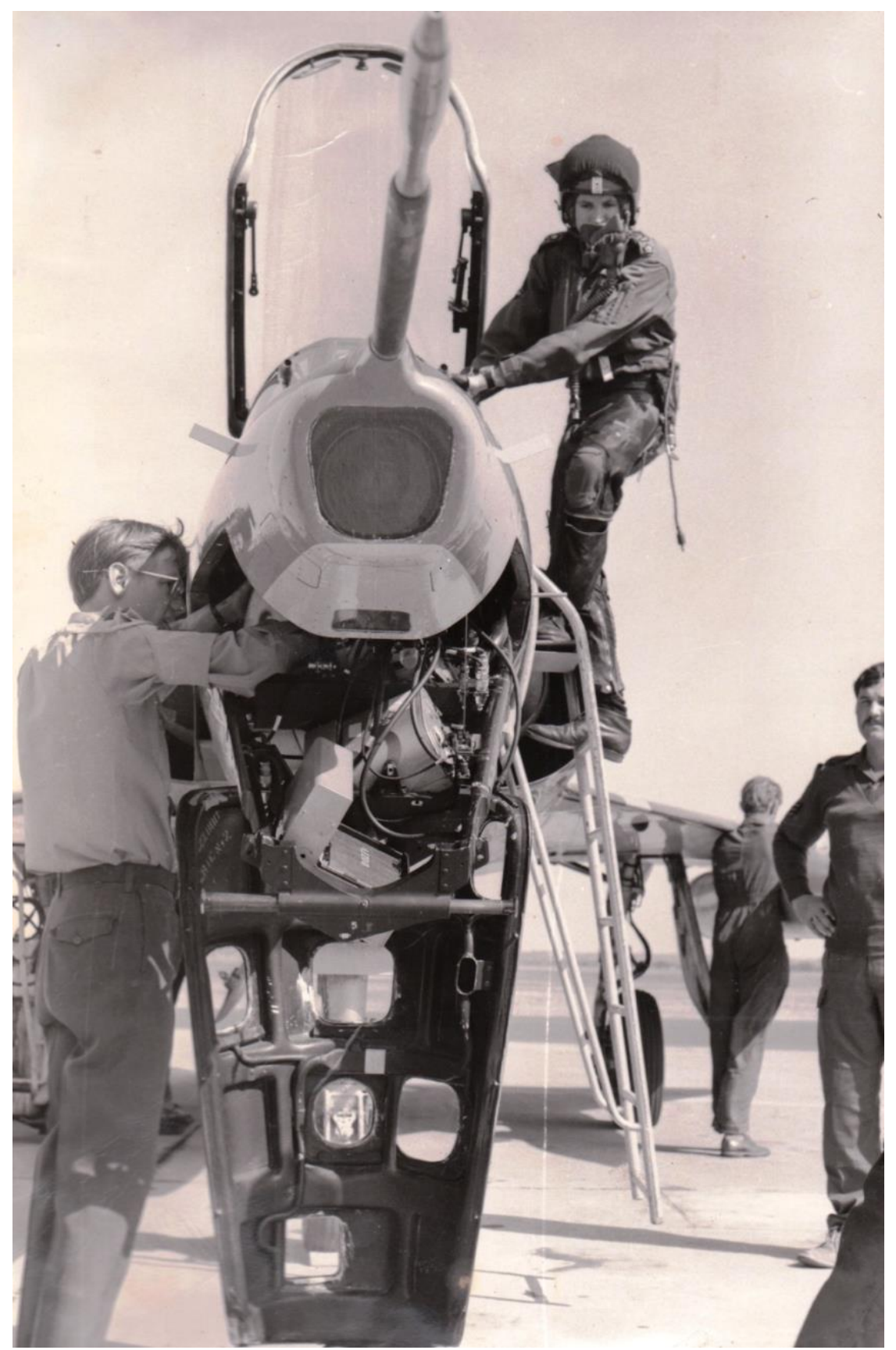

Figure 3. Installation of the camera at the nose of the Mirage, 1976. (Airforce Museum, Cape Town).

Consider the repair persons, or the "spanner tiffies" as they were called in the South African Air Force. In figure 3 above we see a man on the left reaching inside the nose of the plane. His actions - as much as those of technicians like him - were composed of in a sequence that integrated several gestures. New goals 
were redefined by new associations and the number of actors - both social and technical-varies from step to step. With each calibration to the photographic equipment a background of skills, training and technique made him an obligatory passage point (Callon 1984), that is, an indispensable part of the network that made the production of aerial photographs possible. Although remote in time and space when the picture of the $\mathrm{S}$. molesta and Ngoma Bridge were taken (see figure 2), he was simultaneously active and present through its production. ${ }^{11}$

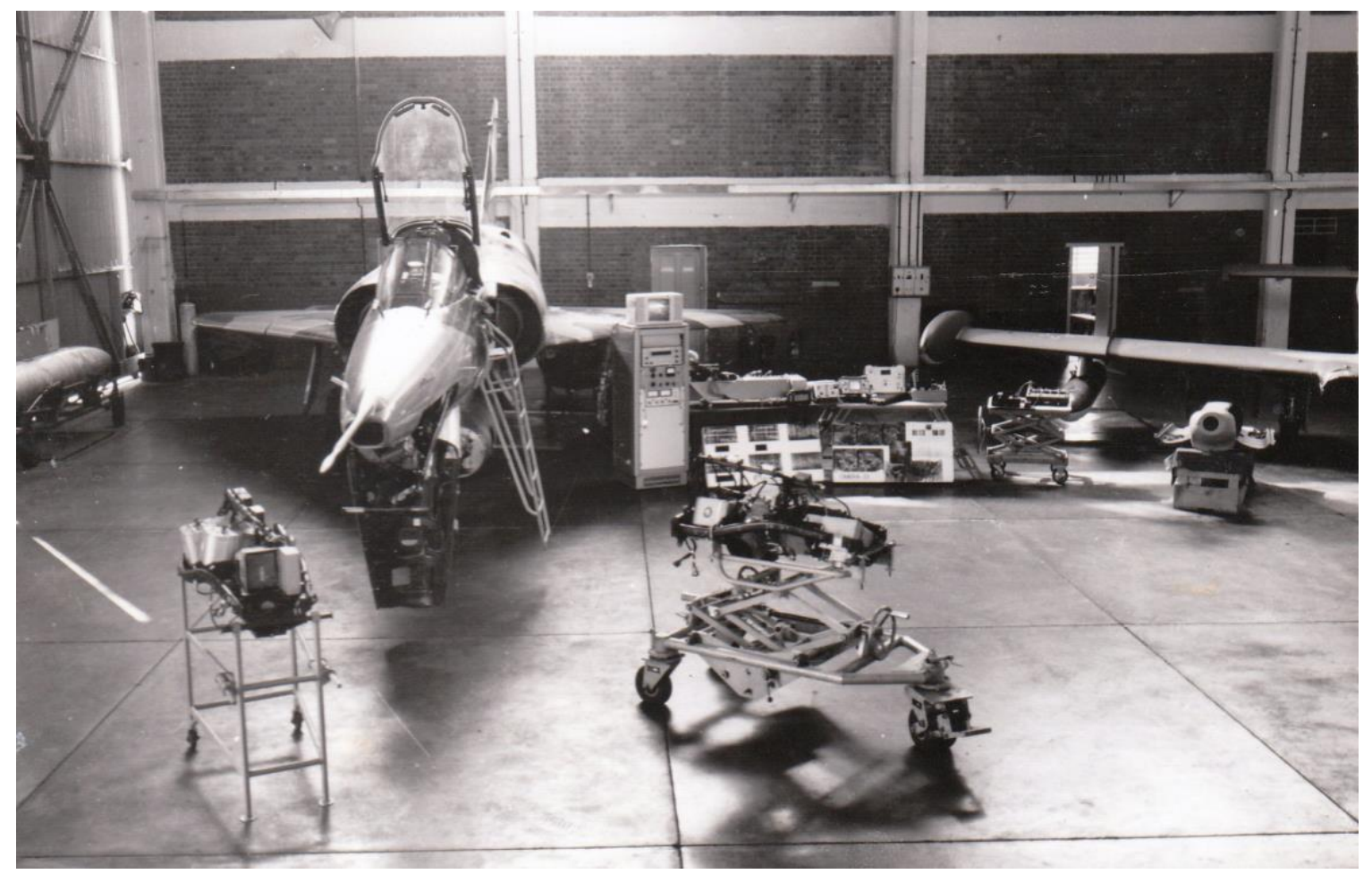

Figure 4. The Mirage undergoing modifications at Denel, 1976. (Airforce Museum, Cape Town).

The Mirage IIIR2Z is a technical artefact made up of other artefacts and silent actors ranging from the people who load film into the camera to the production of the film and cameras themselves. One of these technical delegates is a stand seen in the middle of the photograph which was used to build the camera pack that would be jacked up into the nose of the plane using a dolly that we see on the image's right. After the mission, the film could be easily extracted and brought to the South African Defence Force's own dark rooms to be developed. ${ }^{12}$ In certain versions of the Mirage IIIR there were three OMERA 33 cameras located in the

${ }^{11}$ For a fuller account of the skills involved in aerial photography interpretation, see Jeanne Haffner's elaboration in Chapter 1 "From Enthusiasm to Expertise: Aerial Vision from Before the Airplane to the Aftermath of World War I." (2013).

${ }^{12}$ For an example, see this video available on youtube.com at 1 minute 46 seconds (2019). 
nose as low level, medium level, high level and a lateral oblique. Later versions (the IIIR2Z for instance) contained a newer and more powerful engine and the nose carried five OMERA 31 optical cameras capable of focusing in four different arrangements for ultra-low, medium, high and night missions (Jackson 1985, 27). Even later versions of the Mirage IIIR2Z housed either a 75mm OMERA 40 panoramic camera or a $150 \mathrm{~mm}$ OMERA 33 vertical camera, thereby increasing the resolution of images used by the military or nature conservationists.

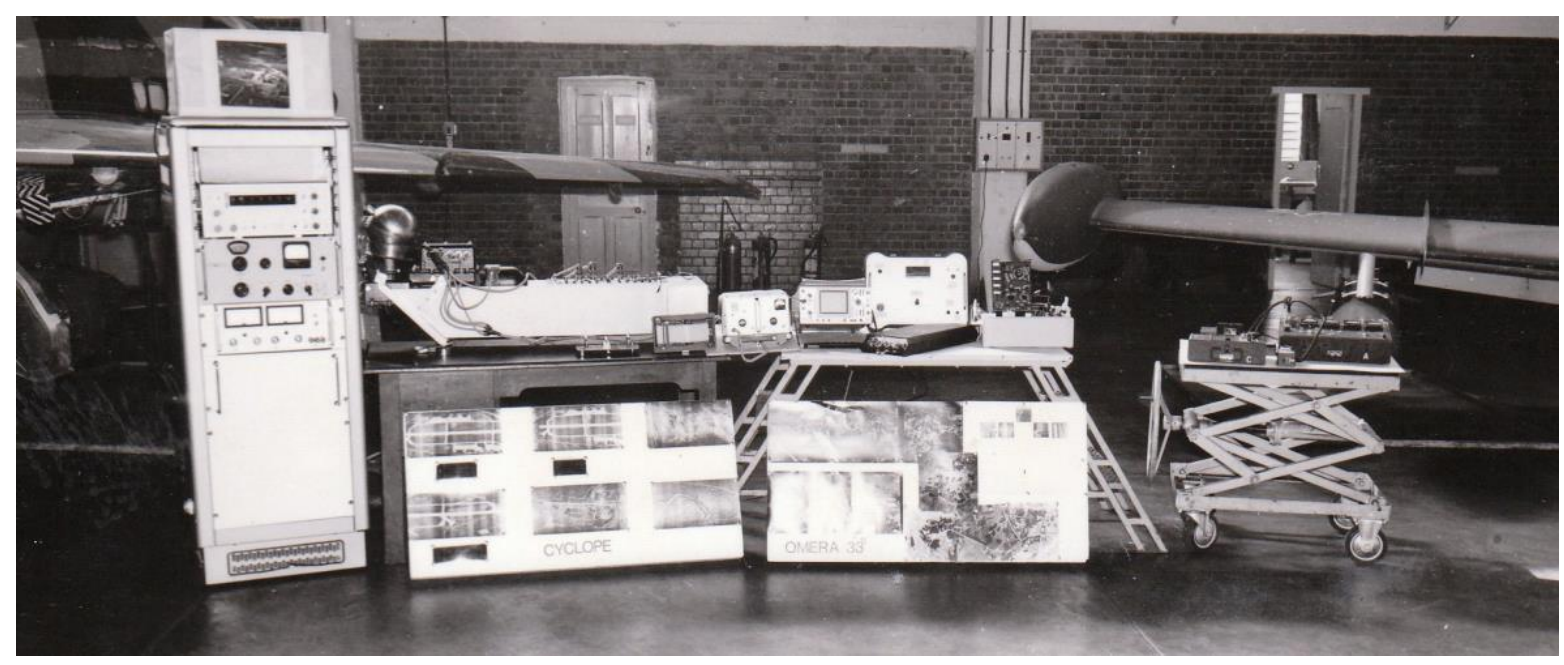

Figure 5. The photographic equipment, 1976. (Air Force Museum, Cape Town).

In addition to the photographic equipment (see figure 5) in the nose, there was an infrared line scan reconnaissance system (called Cyclopes) mounted on the belly near the fuel tank, which replaced the starboard gun in the case of the Mirage IIIR2Z variant. In the above image we see that, to the right, are the test benches for the infrared line scan camera, and we see the SAT Cyclopes which produced multi-spectral photography. The Cyclopes scanner provided thermal and hydrological information on the depth of the analyzed terrain and was used for remote sensing techniques to register vegetation, human activities, and water dynamics. This information was useful both for the civil administration of the Caprivi to control $S$. molesta as well as for the military to fight against the enemy.

\section{"Firming Up"}

"Left button picture, right button bomb" epitomizes the convergence of the technological assemblage inside the cockpit of a Mirage IIIR2Z dual tactical strike and reconnaissance jet, which we position as the anchor of a shared infrastructure of spatial knowledge production for both nature conservation and military strategy. Given the Mirage's multiplicity, the question to be addressed is how such a technology takes shape from global and locally shaped networks as well as how it underpinned certain programs of action.

With Latour's vocabulary, we are able to look closer at the parts through which action was distributed, particularly in the production of aerial photographs, and how this action was distributed amongst a network of ecologists, technologists and military. Within this logic, the production of an aerial photograph is not the action of a single actor, but rather the result of a whole association of entities (both human and non-human) including animals, concepts, devices, people, plants, and skills. They are invisible 
actors in a network through which action-like taking a picture or dropping a bomb - is mediated. Looking at aerial photographs in this way means approaching them not as the beginning but the end of a whole chain of "technical mediators," whose actions are not directly visible in a single picture (Latour 1994, 45; Latour 1999, 192).

Latour's symmetrical argument distributes action across subject and object (i.e., pilots, fighter jets, and institutions) which is part of a wider attempt to find a vocabulary to describe the ways in which society and technology are mutually constituted (Bijker and Law 1992). Although we find Latour's argumentation useful in terms of unpacking green militarization as a shared infrastructure, we do recognize the danger of "technical mediation" being used to excuse individual actions, like for example in the case of using the Mirage for atrocities against civilians and the distribution of agency for committing such crimes to individual people. Nevertheless, we think it is useful to apply this frame of reference to understand the importance of military technology in discussing (green) violence and the militarization of conservation precisely because it directs our attention to the ways in which technology and society are entangled.

While the Latourian analysis taken up in this article accounts for certain aspects of technical mediation, it results in a politics that is contingently emergent from the interactions between particular artifacts or technologies and different actors and interests. What is lacking is an account of the contingently emergent forms which are part of a longer cultural and political history of the relationship between military and conservation politics in Southern Africa as a whole (Ellis 1994; Lenggenhager 2018). Thus, any analysis explicating the history of the intertwined character of conservation and military politics in Southern Africa needs to signal an awareness of the wider developments. The work of Jane Carruthers (2001), for instance, provides us with background to conclude that there is nothing inevitable about the form and function of certain technologies that sit between scientific knowledge production, military strategy and the production of nature-spaces.

Society and technology actualized within the particular history of militarized and oppressive nature conservation in Southern Africa and technological relationships "firmed up" within these heterogenous social, political, historical, economic and cultural conditions (Bijker and Law 1992, 8). Or, in a Simondonian sense (1958), the Mirage IIIR2Z was actualized within a particular milieu during the Namibian War of Liberation and the South African military's need to understand the Caprivian landscape as a particular kind of space. This need to represent the landscape thereby drew nature conservation and the South African Defence Force together, giving rise to a shared infrastructure of which the Mirage was a central part. The question to ask is, therefore, how do certain technologies shape and become shaped by the actual circumstances in which they operate? Addressing this means addressing the relationship between economy, state, military and conservation agendas which give rise to green militarization against a historical backdrop of the interrelations between military and conservation interests in the region. The following gestures toward our conclusion which is based on how the development of the Mirage IIIR2Z put in place structures in which more recent technologies in the context of green militarization have taken shape.

By the late 1980s most Mirage III variants were taken out of service and replaced by the modified Atlas Cheetah. The SAAF's Mirage fleet was upgraded to match the Israeli Kfir C2s, a type of combat aircraft that included new radar and fire control. The refurbishment was done by the South African Atlas Aircraft Corporation in collaboration with Israeli firms, who solicited their technical assistance to convert existing Mirage III airframes into the Atlas Cheetah which entered service in 1987 while the South African Defence 
Force was still active against the South West African People's Organization (SWAPO) and supporting Unita fighters in Angola (Jackson 1985, 54-55). ${ }^{13}$ By this time, some Mirages-such as the IIIRCZ-were considered obsolete but were dedicated to secondary roles in the conflict, such as daytime interception, base

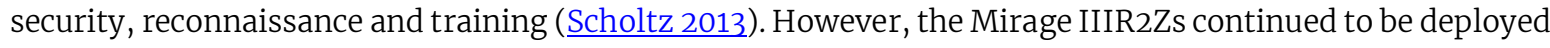
for photo reconnaissance missions over Angolan targets until the South African Defence Force withdrew from Namibia in 1989 (Lord 2008).

In 1992 the Atlas Aircraft Corporation was absorbed within Denel Aviation which continues to provide nature conservationists in South Africa with aerial surveillance technologies, now in the form of Unmanned Aerial Vehicles (UAV, or "drones") in order to provide sophisticated detection and tracking equipment to improve intelligence gathering and observation. ${ }^{14}$ South Africa's nearly forty-year history of military drone development began with the Champion, a prototype developed by the South African Council for Scientific and Industrial Research in 1977. The device was delivered to the South African Air Force the following year for use during the Zimbabwean Liberation struggle (1964-1979). Between 1980 and 1987 a fleet of South African and Israeli drones flew combat operations from Mozambique to Angola (andvik 2015).

More recently, in 2015, Denel Dynamics introduced the Snyper and in 2016 the Paramount Groupa privately owned aerospace company - provided South African National Parks (SANParks) with the Seeker MKII surveillance airplane and training for military style anti-poaching operations (Lunstrum 2018). Drones now constitute a dominant technological feature of the so-called "war against poachers" and the protection of high-value wildlife from human "enemies." Within the euphemistically called Peace Parks-or Transfrontier Conservation Areas (TFCAs) - drones create and uphold spatial regimes within which the identities of people, plants and animals shift on unstable grounds, where a person hunting is transformed into a person poaching (Mavhunga 2014).

Drone technology therefore has to be understood as part of a productive and historically embedded power regime of aerial reconnaissance with links between the South African National Defence Force (SADF) and nature conservation. Like the Mirage IIIR2Z, drones sit at the intersection of violence, institutions, mapping practices, knowledge regimes and historicizing their development in Southern Africa reveals a legacy of technological imperialism and colonial airpower embedded within an apparatus of surveillance, reconnaissance, documentation and nature conservation (Dedering 2015). Something is gained in this analysis by "shifting down" to explore the many technical delegates that made possible a shared infrastructure that is firmed up out of historical links between industry and territorial interests. And as they pass from one instruction to another, technologies are shaped and reshaped by heterogeneous processes that were shaped by the interaction between military and nature conservation. The Mirage IIIR2Z was a

\footnotetext{
${ }^{13}$ At the time, Israel was one of the few countries that had not sanctioned the export of military equipment to South Africa and was - like South Africa - isolated by a French arms embargo after the passage of United Nations Security Council Resolution 418, in November 1977 (Cock and Nathan 1989).

${ }^{14}$ See Masse et al. for more on the relationship between Denel and current connections between conservation and war (2016).
} 
particular kind of technical object that consolidated the relationship between the armed forces and nature conservation, an uncanny pairing in the hands of a racist regime with imperial ambitions in Namibia.

\section{Conclusion}

During South Africa's belligerent wars along Southern African borders, an intimacy formed between people and their machines, a relationship that incorporated technologies in prosthetic relationship with the human body (Hayes 2001). Aerial photography emerged from the fusing together of a person, aircraft and camera. Patricia Hayes acknowledges the gun-camera connection in terms of "its full destructive heights in the latter part of the twentieth century" whereby the gun and the camera were not parallel but were "fused together as one tool on the same machine: the aeroplane" (ibid., 134). The Mirage fighter jet holds together the political, technological and social dimensions of a conservation-military nexus that developed in the 1970s in the remote border areas of north-eastern Namibia. This nexus continues to affect the lives of people living there in terms of creating the conditions within which the deadly use of military technology has become socially acceptable and normalized in the fight against poaching and the protection of nature.

The title of our paper "left button picture, right button bomb," suggests that spatial knowledge production was a necessary means through which the SADF addressed its objectives which crossed over to nature conservation. S. molesta engendered close collaboration between civil and military personnel, who used the same infrastructures to create a shared spatiality on the basis of aerial photographs. The alien plant - as one of many heterogeneous forces - strengthened the collaboration between the military and civil nature conservation officials and the resultant spatial ordering continues to define the region as an area of inclusion and exclusion. However, it is not only the boundaries drawn by conservationists and the military that created the conditions within which green violence emerged. Our first vignette about the alleged poachers shot by the Botswanan military clarified that technology still plays a central role in conservation and the militarized format it often takes in Southern Africa. New forms of shared infrastructures are emerging that allow for the surveillance and control of people in the name of nature conservation, the best known being the UAVs used by anti-poaching troops as well as by conservationists in this border region.

Recent developments show that the military-conservation nexus is still strongly impacting the lives of people and animals in north-eastern Namibia. In November 2020, the tension at the BotswananNamibian border intensified after a family of four were shot dead by the BDF. Similar to the situation that we described at the beginning of this paper, the family was - according to the first media reports - unarmed and shot dead on the basis of Botswana's "shoot to kill" policy because they were suspected to be members of a poaching syndicate. While the 2016 shooting did not (yet) lead to major public outcry, this has changed. People in the region have been attacking Botswanan trucks, there were growing protest marches in the capital and an editor of the largest Namibian newspaper called the "extrajudicial execution" of alleged poachers by the BDF a "regional security issue" that "may trigger wars between the neighboring countries." (The Namibian 2020b). The collaboration and connections between military and conservation entail more than shooting of alleged poachers by the military. The military-conservation nexus has shown diverse faces in the region's past and present through the sharing of infrastructure, joint surveillance activities, and exchange of personnel and experts as well as in regard to shared enemies; such as invasive species in our case, or trespassers in the case of the recent BDF shootings. As this paper has shown, understanding the 
diverse manifestations of the military-conservation nexus needs to be embedded in the particular local history and context.

This history and its continuity showcase the development of weapons and research tools - as in the dual use functions of drones and reconnaissance fighter jets-which sheds a critical light on the development of technological systems in Southern Africa that relate to the domains of nature conservation, militarization and spatial knowledge. The particular historical and geographical context in which nature conservation and warfare come together lends itself to a deeper understanding of the processes through which violence and the production of space are mediated. In treating certain technological artefacts and their inscriptions as multiple, we appreciate the social and historical contingencies in which technoscientific assemblages take shape at the confluence of war and nature. This approach not only historicizes the "war on poaching" that we are currently witnessing in Southern Africa, but also illustrates how recent political debates about the use of violence and military tactics in wildlife conservation in Southern Africa allow us to rethink concepts in STS. For instance, that action is distributed across technologies (Latour 1994; 1999) which are simultaneously shaped by historical, economic, political, social and environmental arrangements that embody the interplay of professional, technical and environmental factors (Bijker and Law 1992). Moreover, our study of the Mirage IIIR2Z shows that technological change in the domains of conservation and militarization is the product of structures that were already put in place, which have damaging implications for other actions and arrangements in terms of human-non-human relations.

\section{Acknowledgments}

We would like to thank Lorena Rizzo for reading an earlier version and for providing crucial feedback. And a special thanks to the reviewers whose generous feedback steered this article in the right direction.

\section{Author Biography}

James Merron is a postdoctoral researcher and lecturer at the Centre for African Studies, University Of Basel.

Luregn Lenggenhager is a postdoctoral researcher and lecturer at the Centre for African Studies, University Of Basel.

\section{References}

Ally, Shireen, and Ariana Lissoni, eds. 2018. New Histories of South Africa's Apartheid-Era Bantustans. Milton Park: Routledge.

Barbora, Sanjay. 2017. "Riding the Rhino: Conservation, Conflicts, and Militarisation of Kaziranga National Park in Assam." Antipode 49(5): 1145-1163.

Bollig, Michael, and Hauke-Peter Vehrs. 2021. "The Making of a Conservation Landscape: The Emergence of a Conservationist Environmental Infrastructure along the Kwando River in Namibia's Zambezi Region." Africa 91(2): 270-295.

Bousquet, Antoine. 2018. The Eye of War: Military Perception from the Telescope to the Drone. Minneapolis: University of Minnesota Press.

Bijker, Wiebe. E., and John Law. 1992. Shaping Technology/Building Society. Cambridge: MIT Press.

Breytenbach, Jan. 1997. Eden's Exile: One Soldier's Fight for Paradise. Cape Town: Queillerie Publishers. 
Brindley, John. F. 1971. Aircraft Profile: Dassault Mirage Variants. London: Profile Publishers Ltd.

Büscher, Bram. 2013. Transforming the Frontier: Peace Parks and the Politics of Neoliberal Conservation in Southern Africa. Durham: Duke University Press.

Büscher, Bram. 2016. "'Rhino Poaching is Out of Control!' Violence, Race and the Politics of Hysteria in Online Conservation." Environment and Planning A 48(5): 979-98.

—, and Maano Ramutsindela. 2016. "Green Violence: Rhino Poaching and the War to Save Southern Africa's Peace Parks." African Affairs 115(458): 1-22.

Callon, Michel. 1984. "Some Elements of a Sociology of Translation: Domestication of the Scallops and the Fishermen of St Brieuc Bay." The Sociological Review 32: 196-233.

Carruthers, Jane. 2001. Wildlife \& Warfare: The Life of James Stevenson-Hamilton. Pietermaritzburg: University of Kwazulu-Natal Press.

Certini, Giacomo., Riccardo Scalenghe, and William I. Woods. 2013. "The Impact of Warfare on the Soil Environment." Earth-Science Reviews 127: 1-15.

Cock, Jacklyn., and Laurie. Nathan. 1989. War and Society: The Militarization of South Africa. Cape Town: New Africa Books.

Cosgrove, Denis. E. 2001. Apollo's Eye: A Cartographic Genealogy of the Earth in the Western Imagination. Baltimore: John Hopkins University Press.

Dale, 2014. The Namibian War of Independence, 1966-1989: Diplomatic, Economic and Military Campaigns. Jefferson: Mc Farland and Company.

Dedering, Tilman. 2015. "Air Power in South Africa, 1914-1939." Journal of Southern African Studies 41(3): 451-465.

Duffy, Rosaleen. 2016. "War, by Conservation." Geoforum 69: 238-48.

Dunlap, Alexander, and James Fairhead. 2014. "The Militarisation and Marketisation of Nature: An Alternative Lens to 'Climate-Conflict.'" Geopolitics 19(4): 937-61.

Edwards, Paul N. 1997. "Why Build Computers?: The Military Role in Computer Research," in The Closed World: Computers and the Politics of Discourse in Cold War America. Cambridge: MIT Press: 54-74.

Edwards, D., and P. L. Thomas. [1979] 2016. "The Salvinia Molesta Problem in the Northern Botswana and Eastern Caprivi Area." Secretary for Agriculture. National Archives of Namibia, Caprivi Agriculture and Forestry (CAF).

Ellis, Stephen. 1994. "Of Elephants and Men: Politics and Nature Conservation in South Africa." Journal of Southern African Studies 20(1): 1-17.

Eloff De Visser, Lieneke. 2011. "Winning Hearts and Minds in the Namibian Border War." Scientia Militaria South African Journal of Military Studies 39(1): 85-100.

Garland, Elizabeth. 2008. "The Elephant in the Room: Confronting the Colonial Character of Wildlife Conservation in Africa." African Studies Review 51(3): 51-74.

Global Witness. 2021. On Dangerous Ground. Accessed July 23, 2021.

https://www.globalwitness.org/en/campaigns/environmental-activists/dangerous-ground/.

Haffner, Jeanne. 2013. The View from Above: The Science of Social Space. Cambridge MIT Press.

Hayes, Patricia. 2001. "Vision and Violence: Photographies of War in Southern Angola and Northern Namibia." Kronos 27: 133-57.

Jackson, Paul A. 1993. "Mirage III/5/50 Variant Briefing." World Air Power Journal 14: 112-137. 
1985. Mirage. Modern Combat Aircraft 23. London: Ian Allan Ltd.

Jensen, Steffen, and Olaf Zenker. 2015. "Homelands as Frontiers: Apartheid's Loose Ends." Journal for Southern African Studies 41 (5): 937-952.

Kangumu, Bennett. 2011. Contesting Caprivi: A History of Colonial Isolation and Regional Nationalism in Namibia. Basel: Basler Afrika Bibliographien.

Latour, Bruno. 1994. "On Technical Mediation." Common Knowledge 3(2): 29-64.

-1999. Pandora's Hope: Essays on the Reality of Science Studies. Cambridge: Harvard University Press.

Law, John. 2002. Aircraft Stories: Decentering the Object in Technoscience. Durham: Duke University Press.

Lawrence, Michael. J., Holly L. Stemberger, Aaron J. Zolderdo, Daniel P. Struthers, et al. 2015. "The Effects of Modern War and Military Activities on Biodiversity and the Environment." Environmental Reviews 23(4): 443-460

Lenggenhager, Luregn. 2015. "Nature, War and Development: South Africa's Caprivi Strip, 1960-1980." Journal of Southern African Studies 41(3): 467-83.

- 2018. Ruling Nature, Controlling People: Nature Conservation, Development and War in North-Eastern Namibia Since the 1920s. Basel: Basler Afrika Bibliographien.

Lord, D. 2008. From Fledgling to Eagle: The South African Air Force During the Border War. Pinetown: $30^{\circ}$ South Publishers.

Lunstrum, Elizabeth. 2014. "Green Militarization: Anti-Poaching Efforts and the Spatial Contours of Kruger National Park." Annals of the Association of American Geographers 104 (4): 816-32.

-2015. "Conservation Meets Militarization in Kruger National Park: Historical Encounters and Complex Legacies." Conservation and Society 13 (4): 356-69.

—. 2018. "Capitalism, Wealth, and Conservation in the Age of Security: The Vitalization of the State." Annals of the American Association of Geographers 108(4): 1022-37.

Mack, Pamela E. 1990. Viewing the Earth: The Social Construction of the Landsat satellite system. Cambridge: MIT Press.

Marijnen, Esther. 2017. "The 'Green Militarisation' of Development Aid: The European Commission and the Virunga National Park, DR Congo." Third World Quarterly 38(7): 1566-1582.

Marlantes, Karl. 2009. Matterhorn. Berkeley: El Leon Literary Arts.

Massé, Francis, and Elizabeth Lunstrum. 2016. "Accumulation by Securitization: Commercial Poaching, Neoliberal Conservation, and the Creation of New Wildlife Frontiers." Geoforum 69: 227-37.

_ - Elizabeth Lunstrum, and Devin Holterman. 2018. "Linking Green Militarization and Critical Military Studies." Critical Military Studies, 4(2): 201-221.

Mavhunga, Chakanetsa C. 2014. Transient Workspaces: Technologies of Everyday Innovation in Zimbabwe. Cambridge: MIT Press.

Neumann, Rod. 2005. Making Political Ecology: Human Geography in the Making. Oxford: Oxford University Press.

Ntibinyane, Ntibinyane, Tileni Mongudhi, and Joel Konopo. 2016. "Botswana's 'Shoot-to-kill Policy' Against Suspected Poachers." Mail \& Guardian, March 18, 2016. https://mg.co.za/article/2016-0318-00-botswanas-shoot-to-kill-policy-against-suspected-poachers/.

Ramutsindela, Maano. 2007. Transfrontier Conservation in Africa: At the Confluence of Capital, Politics and Nature. Wallingford: Cabi. 
—. Innocent Sinthumule. 2017. "Property and Difference in Nature Conservation." Geographical Review, 107(3): 415-432.

Rizzo, Lorena. 2019. Photography and History in Colonial Southern Africa: Shades of Empire. Johannesburg: Routledge and Wits University Press.

Robbins, Paul. 2012. Political Ecology: A Critical Introduction. Hoboken: John Wiley \& Sons.

Russell, Edmund and Richard P. Tuckers. 2004. "Introduction" in Natural Enemy, Natural Ally. Toward an Environmental History of War, edited by R.P. Tucker and E. Russell. Oregon State University Press. 115.

Sandvik, Kristin B. 2015. "African Drone Stories.” Behemoth: A Journal on Civilization 8 (2): 73-96.

SANParks. 2012a. Media Release: SANParks and Private Sector Take Rhino Poaching to the Skies. Accessed April 10, 2020. http://www.sanparks.org/about/news/ default.php?idD55378.

—. 2012b. Denel and SANParks sign landmark agreement to combat rhino poaching. Accessed April 10, 2020. https://www.sanparks.org/about/news/default.php?id=55361.

—. 2013. Battle for SA's rhino takes to the air at $310 \mathrm{~km}$ per hour. Accessed April 10, 2020. https://www.sanparks.org/about/news/default.php?id=55944.

—. 2014. Media release: Howard Buffett R255 million donation to rhino conservation. Accessed April 10, 2020. https://www.sanparks.org/about/news/?idD56022.

Shinn, Terry, and Bernward Joerges. 2002. "The Transverse Science and Technology Culture: Dynamics and Roles of Research-Technology." Social Science Information 41(2): 207-51.

Singh, Jaidev, and Henk van Houtum. 2002. "Post-Colonial Nature Conservation in Southern Africa: Same Emperors, New Clothes?" GeoJournal 58(4): 253-263.

Scholtz, Leopold. 2013. The SADF in the Border War: 1966-1989. Cape Town: Tafelberg.

Simondon, Gilbert. 1958. On the Mode of Existence of Technical Objects, translated by Ninian Mallamphy. Aubier: Editions Montaigne.

Source Unknown. 2019. MIRAGE III Film Dassault Aviation. Accessed July 232021. https://www.youtube.com/watch?v=1b2UvTZWRWA.

Spierenburg, Marja, and Harry Wels. 2010. "Conservative Philanthropists, Royalty and Business elites in Nature Conservation in Southern Africa." Antipode, 42(3): 647-670.

The Namibian. 2020a. Four Nam Fishermen Killed Along Chobe. Accessed July 23, 2021. https://www.namibian.com.na/206112/archive-read/Four-Nam-fishermen-killed-along-Chobe.

The Namibian. 2020b. Botswana's Border Aggression is a Regional Security Issue. Accessed July 23, 2021. https://www.namibian.com.na/206294/archive-read/Botswanas-Border-Aggression-is-aRegional-Security-Issue.

Tucker, Richard T., and Edmund Russell. eds. 2004. Natural Enemy, Natural Ally. Toward an Environmental History of War. Corvallis: Oregon State University Press.

Verweijen, Judith, and Esther Marijnen. 2018. "The Counterinsurgency/Conservation Nexus: Guerrilla Livelihoods and the Dynamics of Conflict and Violence in the Virunga National Park, Democratic Republic of the Congo." The Journal of Peasant Studies 45(2): 300-320.

Wels, Harry. 2015. Securing Wilderness Landscapes in South Africa: Nick Steele, Private Wildlife Conservancies and Saving Rhinos. Leiden: Brill.

Westing, Arthur H.1976. Ecological Consequences of the Second Indochina War. Stockholm: Almqvist \& Wiksell. 
Williams, Christian. 2015. National Liberation in Post-Colonial Southern Africa: A Historical Ethnography of SWAPO's Exile Camps. Cambridge: Cambridge University Press.

Witter, Rebecca, and Terre Satterfield. 2019. "Rhino Poaching and the "Slow Violence" of Conservationrelated Resettlement in Mozambique's Limpopo National Park." Geoforum 101: 275-84.

Ybarra, Megan. 2012. "Taming the Jungle, Saving the Maya Forest: Sedimented Counterinsurgency Practices in Contemporary Guatemalan Conservation." Journal of Peasant Studies 39(2): 479-502. 